Gi respons på artikler gjennom artiklenes kommentarfelt på tidsskriftet.no. Innleggene publiseres fortløpende på Tidsskriftets nettside og et utvalg av innleggene publiseres også i papirutgaven i spalten «Brev til redaktøren».

Redaksjonen forbeholder seg retten til å foreta redaksjonelle endringer.

Forfattere av vitenskapelige artikler har tilsvarsrett, jf. Vancouver-gruppens regler.

\section{Re: En kvinne i 70-årene med rask forverring av kognitiv funksjon}

Takk for en ny, spennende diagnosejakt med En kvinne i 70-årene med rask forverring av kognitiv funksjon (1). En av vurderingene under utredningen gjentar en utbredt misforståelse: «Normale verdier for albumin (...) pekte ikke i retning av symptomgivende ernæringssvikt.» Nå er det nettopp en usminket og uredigert fremstilling av hva legene tenkte der og da, som kan være feil, som gjør Noe å lære av-spalten troverdig og viktig. Men siden misforståelsen denne gangen ikke blir diskutert senere i artikkelen, kan det være på sin plass å minne om at albumin ikke er en ernæringsmarkør. Det viser også denne sykehistorien: «Vår pasient hadde ernæringssvikt (...)», og det faktum at avmagrede anoreksipasienter har normalt albumin (2). På den annen side kan avmagrede akutt syke pasienter ha lav albumin. Da er det viktig å kjenne til at årsaken i de fleste tilfeller skyldes kapillær lekkasje pga. inflammasjon, og ikke slå seg til ro med at underernæring er forklaringen (3).

\section{Erik Waage Nielsen}

erikwn@me.com

Erik Waage Nielsen (f. 1956) er overlege og professor ved Nordlandssykehuset.

Ingen oppgitte interessekonflikter.

\section{Litteratur}

1. Reiakvam KK, Astor MC, Kittang BR. En kvinne i 70-årene med rask forverring av kognitiv funksjon. Tidsskr Nor Legeforen 2016; 136: 1096-8.

2. Huysentruyt K, De Schepper J, Vanbesien J et al. Albumin and pre-albumin levels do not reflect the nutritional status of female adolescents with restrictive eating disorders. Acta Paediatr 2016; 105: e167-9.

3. Nicholson JP, Wolmarans MR, Park GR. The role of albumin in critical illness. $\mathrm{Br} J$ Anaesth 2000; 85: 599-610.

\section{K.K. Reiakvam \& B.R. Kittang svarer:}

Vi takker Waage Nilsen for kommentar om albumin og underernæring. Vi er enige $i$ at normale verdier for albumin ikke utelukker ernæringssvikt, og at lave verdier av albumin kan skyldes mange ting, inkludert inflammasjon, overhydrering, lekkasje til ekstracellulærvæsken i forbindelse med akutt alvorlig sykdom, økt tap via f.eks. brannskader og syntesesvikt relatert til blant annet leversykdom, akuttfasereaksjoner - og underernæring (1).

Waage Nilsen har også helt rett $\mathrm{i}$ at vi har prøvd å gjengi medisinske vurderinger gjort underveis på en «usminket» måte. Vi vil også presisere at den primære vurderingen av sammenhengen mellom pasientens symptomer, antatte ernæringsstatus og tolkning av prøvesvar ikke alene hvilte på en vurdering av albuminverdien, men også andre parametre, som gjengitt $\mathrm{i}$ artikkelen: «Normale verdier for albumin, kalsium, kalium, vitamin $B_{12}$ og folat pekte ikke i retning av symptomgivende ernæringssvikt». Vi var dessuten bevisst på ikke å skrive at funnene pekte bort fra diagnosen underernæring.

Da er det kanskje ikke så paradoksalt at vi, med et retrospektivt og mer nyansert blikk for detaljene i sykdomsprosessen, konkluderer med at pasientens magnesiummangel trolig skyldtes «mangelfull ernæring og bruk av protonpumpehemmer». At albumin som (problematisk) markør for underernæring kunne vært viet plass i diskusjonsdelen, er vi ikke uenig i. Nettopp derfor er vi takknemlig for kommentarer som dette.

\section{Kyrre Kittang Reiakvam \\ reiakvam@gmail.com}

Bård Reiakvam Kittang

Kyrre Kittang Reiakvam (f. 1975) er overlege ved medisinsk avdeling, Haraldsplass Diakonale Sykehus.

Ingen oppgitte interessekonflikter.

Bård Reiakvam Kittang (f. 1971) er overlege, ph.d. og spesialist i indremedisin og i infeksjonssykdommer.

Ingen oppgitte interessekonflikter.

\section{Litteratur}

1. Nasjonal brukerhåndbok i Medisinsk Biokjemi. http://brukerhandboken.no/ index . php?action=showtopic\&topic=e1391e7659a13fc6502a (14.9.2016).

\section{Re: Kjøtt sett i relasjon til evolusjonen}

Det at mennesker genetisk sett er tilpasset til å kunne fordøye kjøtt er på ingen måte ensbetydende med at rødt kjøtt ikke er kreftfremkallende - i motsetning til det man kan få inntrykk av når man leser debattinnlegget til Tor-Erik Widerøe (1).

Widerøe problematiserer, ut fra et evolusjonsperspektiv, konklusjonen til Verdens helseorganisasjon at det er sannsynlig at ubehandlet rødt kjøtt er kreftfremkallende (2). Konklusjonen er et resultat av en grundig og systematisk litteraturgjennomgang, der usikkerhetene om sammenhengen mellom inntak av rødt kjøtt og DNA-forandringer er tatt i betraktning, slik Widerøe påpeker.

Evolusjon omhandler danningen og endringen av arter. Tykktarmskreft og de fleste andre typer kreft, likeså hjerte- og karsykdommer, utvikler seg som regel lenge etter at man har fått og fostret opp avkommet sitt. At individer innen en art bør være kreft- og ellers sykdomsfrie og leve lengst mulig, er neppe viktig for at arten skal kunne klare seg. Med andre ord: Å kunne fordøye kjøtt var viktig for å overleve, ikke for unngå kreft som gammel.

Selv om det er interessant å forske videre på kjøtt og kreft, mener jeg likevel at det å erstatte mesteparten av kjøttet i kosten med belgvekster samt å ha et hovedsakelig plantebasert kosthold ellers er det tryggeste og sunneste for moderne mennesker. I og med at kjøtt er en matvare vi fint kan klare oss uten (3), ser jeg ingen grunn til å ta risikoen.

I motsetning til forskning om kjøtt finnes det mye forskning som konkluderer med at belgvekster kan gi flere helsefordeler $(4,5)$, og at mer plantebaserte kosttyper er sunnere enn et vanlig vestlig, animalskbasert kosthold $(6,7)$.

Det er viktig ikke å skape falsk trygghet. Ja, det er fortsatt mye vi ikke vet, men vi har allerede sterke bevis for at både ubehandlet rødt kjøtt og ferdigprodukter av kjøtt, både hvitt og rødt, øker risikoen for sykdom $(6,7)$.

\section{Tetyana Kalchenko}

post@hepla.no

Tetyana Kalchenko (f. 1974) er overlege ved Oslo universitetssykehus. Forfatteren er leder for foreningen Helsepersonell for plantebasert kosthold (https://hepla.no/). Dette er et ulønnet engasjement.

Ingen oppgitte interessekonflikter. 